\title{
HIP 法による低温動作カソードの作製
}

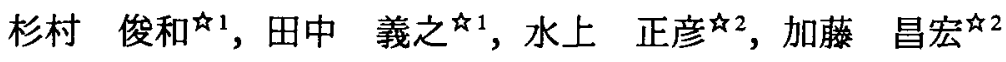

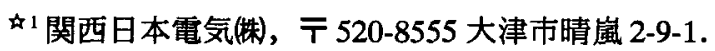 \\ せ2(輩アライドマテリアル，产931-8543 富山市岩瀬古志町 2.
}

\section{Fabrication of Low Temperature Operating Cathode by HIP}

\author{
Toshikazu Sugimura ${ }^{\star 1}$, Yoshiyuki Tanaka ${ }^{\star 1}$, Masahiko Mizukami ${ }^{\star 2}$ and Masahiro Katoh 2 \\ * INEC Kansai, Ltd., 2-9-1 Seiran Otsu 520-8555. \\ \$2ALLIED MATERIAL Corp., 2 Iwasekoshi-machi, Toyama 931-8543.
}

Received December 1, 2000

\section{SYNOPSIS}

Low temperature operating cathodes produced by hot isostatic pressing (HIP) have been developed. This new cathode, which has the advantages of both oxide cathodes and dispenser cathodes, was achieved by HIP, although sintered cathodes have not been successful thus far. Nickel powder and Ba-Sr-Ca carbonate (emitter) powder are mixed, pressed and subsequently encapsulated into a glass capsule under vacuum. HIP was performed at $1373 \mathrm{~K}$ and $130 \mathrm{MPa}$. The carbonate emitter was converted into oxide by heat treatment in a cathode ray tube. The optimized operating temperature of the HIP cathode was $1053 \mathrm{~K}$, which was almost the same as that of oxide cathodes and was $150 \mathrm{~K}$ lower than that of dispenser cathodes. The life test of the HIP cathodes revealed only less than $10 \%$ decay after $30000 \mathrm{~h}$ under a high current density of $3 \mathrm{~A} / \mathrm{cm}^{2}$. In contrast, oxide cathodes showed about $50 \%$ decay after only $1000 \mathrm{~h}$ under the same current density.

KEY WORDS

HIP, emission, carbonate emitter, HIP cathode, oxide cathode, life test

\section{1 緒 言}

CRT (Cathode Ray Tube) は，高真空に保たれたチュープ 中で, 熱電子をカソードより発生させ, これを電子ビームに して電子流を調整し, さらに高電圧で加速, 集束, 必要に応 じて偏向しながら営光面に当てて可視像を描かせる表示テバ イスである. 近年のCRTの大型化, 高精細化の要求を満たす ためには,カソードの微小領域から多量の電子流を発生させ る必要がある.従来広く用いられている酸化物カソードで対 応しようとすると，高抵抗の熱電子放射材 (以下，エミッ夕) を流れる電流によるジュール熱のために寿命が著しく低減す る.このため, 含浸形カソード又は酸化物カソード改良形の 導入により，上記要求への対応を図っている.

含浸形カソード 1) は，タングステン多孔質体中にエミッタ を溶融含浸させた構造であるため, 電気伝導度が高く, 高電 流密度領域での使用に耐え得る特性を有していることから， 1980 年代後半から大型 CRT などに適応されている ${ }^{2-4)}$. しか し，MgやSiを少量添加した Ni キャップ上にエミッタを吹き 付けた構造の酸化物カソードに比べ,(1)動作温度が約 $150 \mathrm{~K}$ 高
い, (2)カソードの製造工程が複雑であるため，初期エミッ ション不良が生じやすい, (3カソードから電子を取り出し， 安定して電子を供給するために必要な枯化時間が長く, 従来 の酸化物カソード枯化工程との整合が悪いなどの問題がある.

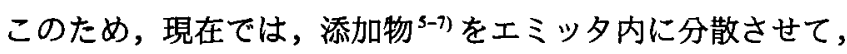
従来の酸化物カソードの長所を保持したまま高電流に耐えら れるように改良された酸化物カソード改良形が開発されてい る. しかし, 2 3A $\mathrm{A} \mathrm{cm}^{2}$ の高電流密度領域における数万時間 の寿命が報告されているが，高電流動作の初期からエミッ ションの劣化が徐々に進行し, 要求電流密度への対応は限界 にきていると考えられる.

そこで, 著者らが先に含浸形カソードに応用した HIP (Hot Isostatic Pressing) 法 ${ }^{8)}$ を，かって試みられたが現行の酸化物力 ソードに対して優位性が見られていない焟結形カソードに適 用して, 酸化物カソードと含浸形カソードの長所を併せ持っ た「低温動作 HIPカソード」を開発した．焼結形カソードは 古くから知られているが，これまで酸化物カソードを超える 性能は得られていない。 
本報では，著者らが開発した低温動作 HIP カソードのコン セプト，作製法及び特性を述へる.

\section{2 低温動作 HIP カソードのコンセプト}

低温動作 HIPカソード開発の组いは，(1)高電流密度下での 寿命特性の向上, (2)酸化物カソードのカソード分解, 枯化工 程との整合, (3) 動作温度の低隇 (酸化物カソードの動作温度 相当),である.これらの性能を有するカソードのコンセフト は以下の通りである.

ペレット内部の発熱を抑え，かつ，機械加エに対するへ レット強度を保つため, 金属 $(\mathrm{Ni})$ 粉末とエミッタとの複合焼 結体にしたままた，酸化物カソードが低温で動作する要因の 一つは, 三元系酸化物 $(\mathrm{Ba}, \mathrm{Sr}, \mathrm{Ca}) \mathrm{O}$ の使用にある.しかし，こ の三元系酸化物は化学的安定性に欠け大気中で扱うことはで きないので, 三元系炭酸塩 $(\mathrm{Ba}, \mathrm{Sr}, \mathrm{Ca}) \mathrm{CO}_{3}$ 粉末をカソード構体 のキャップ上に吹き付け,その後の排気工程において973K以 上で酸化物に変換している.一方,焼結形カソードの場合, 従 来の常圧焼結法では，炭酸塩を使用しても焼結中に炭酸塩が 分解して酸化物になり，大気中の水分を吸収して水酸化物に なる.その結果, エミッション性能が失われてしまい1073K以 下の低温動作か実現できなかった。そこで，著者らは炭酸塭 エミッタを Ni との焼結後も安定に保持させるため, 真空カプ セルに封入した Ni とエミッタの混合物を HIP 装置により高 温，高压処理する製法を採用し， $\mathrm{Ni}$ と炭酸堨エミッ夕を焼結 固化することとした.ここで金属粉として Ni を選んたのは $1400 \mathrm{~K}$ 以下の温度で焼結でき, $\mathrm{Ni}$ は Ba, Sr 及び Ca と相互に固 溶しないからである。

このような方法で大気中にて安定な炭酸堨エミッ夕を金属 中に分散できれば，これまでの焼結カソードでは実行できな かった湿式ダイサー切断，湿式ラップ研磨及び打ち抜きによ
る焼結体のペレット化加エが可能となると思われる．また， 酸化物カソードの製造ライン中の排気工程で, 炭酸塩エミッ タを酸化物エミッタに変換するカソード分解処理を行うこと ができ,枯化処理も同様に酸化物カソードの工程で対応できる.

\section{3 実験方法}

\section{1 カソードペレットの作製}

低温動作 HIP カソードの製造工程の概略図を Fig.1に示す. $\mathrm{Ni}$ 粉末は純度 $99.9 \%$ ，平均粒径が約 $4 \mu \mathrm{m}$ の粉末，エミッ夕は 純度が $99.5 \%$ ，平均粒径 $5.5 \mu \mathrm{m}$ の Ba, $\mathrm{Sr}, \mathrm{Ca}$ のモル比が $5: 4: 1$ の三元系炭酸塩粉末である. $\mathrm{Sc}_{2} \mathrm{O}_{3}$ 粉末は純度が $99.9 \%$ ，平均 粒径が約 $5 \mu \mathrm{m}$ の粉末を使用した. Ni粉末とエミッ夕は体積比 が50:50になるように調合し， $\mathrm{Sc}_{2} \mathrm{O}_{3}$ は $\mathrm{Ni}$ とエミッ夕の総量に 対して 2.5 重量 \% 添加した。これらの粉末を乾式にてシェー カー混合した後, CIP (Cold Isostatic Pressing)により $100 \mathrm{MPa}$ で 一体化成形した。得られた成形体は，窒化ホウ素粉末を介し てパイレックスガラスチューブ内に挿入し， $10^{-3} \mathrm{~Pa}$ ，約 $800 \mathrm{~K}$ でベーキングを行った後, カプセル封止した. 得られたカプ セルは HIP 温度 $1173 \mathrm{~K} \sim 1473 \mathrm{~K}$, 压力 $130 \mathrm{MPa}$ で $1 \mathrm{~h}$ 保持した。 代表的な HIP 処理パターンを Fig.2に示す. まず，1043Kまで は炉内圧力を $5 \mathrm{MPa}$ 以下に保持してカプセルの破損を防ぎ， 次いで，炉内温度を $1043 \mathrm{~K}$ に保持してパイレックスカララスを 軟化させた後，圧力を上昇させた. 炉内温度と炉内圧力を上 昇させ最終保持条件で保持させた後，カプセルが破損しない よう徐々に温度と圧力を低隇させた。得られた焼結体をダイ サーによる湿式切断，湿式ラップ機によって鏡面研磿し，打 ち抜いて $\phi 1.3 \times 0.2 \mathrm{~mm}$ のペレットを作製した。得られたぺ レットをアルキメテス法による密度測定, SEMによる微細組 織の観察, X線回折 $\left(\mathrm{CuK}_{\alpha}\right)$ による生成相の同定及びEPMAに よる元素分析で調查した。

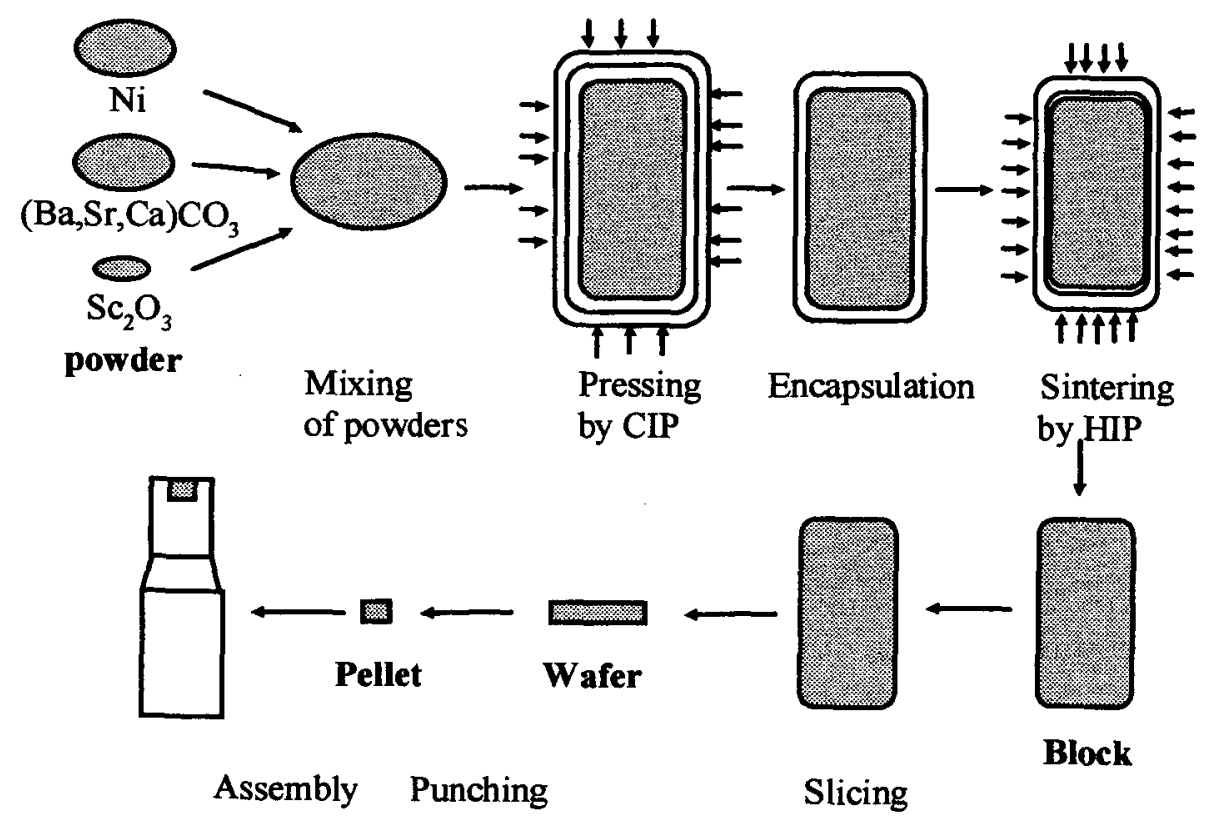

Fig.1 Process of a HIP cathode. 
3.2 カソードの実装及びカソード分解，枯化工程

カソードの実装評価を行うためにペレット, スリーブ及び キャップとの一体化溶接でカソード構体を作製した。 カソー ド構体の構成を Fig.3に示す. 本カソード構体を CRT 内に搭 載した後, カソード分解を行った. 三元系炭酸塩を充分に分 解するためには $1227 \mathrm{~K}$ 以上の温度に加熱する必要があるが， 1473K以上になるとエミッタの劣化が始まることが知られて いるのでカソード分解温度を $1303 \mathrm{~K}$ に設定した.

カソード分解の後, エミッションを継続して安定に放出さ せるためのカソード枯化処理を実施した. カソード枯化処理 は熱活性処理と電流活性処理の 2 段階で行った. 熱活性処理 は, カソードを高温に加熱し，キャップ中の還元剤である $\mathrm{Cr}$ をペレット内に拡散させ, エミッタとの反応を促進させると 同時に遊離 Baを生成させる処理")である. 本実験では, $1353 \mathrm{~K}$ で熱活性処理を行った。

電流活性処理は, エミッション電流の安定化, 電極表面の 電子衝撃による清浄化及び管内ガスのイオン化による真空度 上昇を図るための処理である. 本実験では, 通常の酸化物力 ソードの枯化ラインで設定温度を一部上昇させて実施した.

\section{3 電子放射特性の測定}

電子放射特性は，17インチ CRT を使用し，3極管動作で最 大カソード電流 (MIk) を測定した. MIkは指定条件下でカソー ド電圧を第 1 グリット (G1) と同じ0Vにした時のカソード電 流值である. 正常なカソードの場合, $M I k$ は動作温度にて約 $3000 \mu \mathrm{A}$ のカード電流が得られるエミッション測定回路の構 成になっていることから，本開発においてはエミッション性 能の良否を判断するために, $M I k$ 特性をカソードの性能評価 に用いた。

\section{4 実験結果およひ考察}

\section{1 焼結体の組織}

Fig.4に HIP 処理温度が 1373Kでの電子放射面のEPMA分析 結果を示す. 凝集した Ni 粒子群がエミッタ内に分散し, 少量 の $\mathrm{Sc}_{2} \mathrm{O}_{3}$ 粒子が全体に点在した組織になっている. Fig.5に各

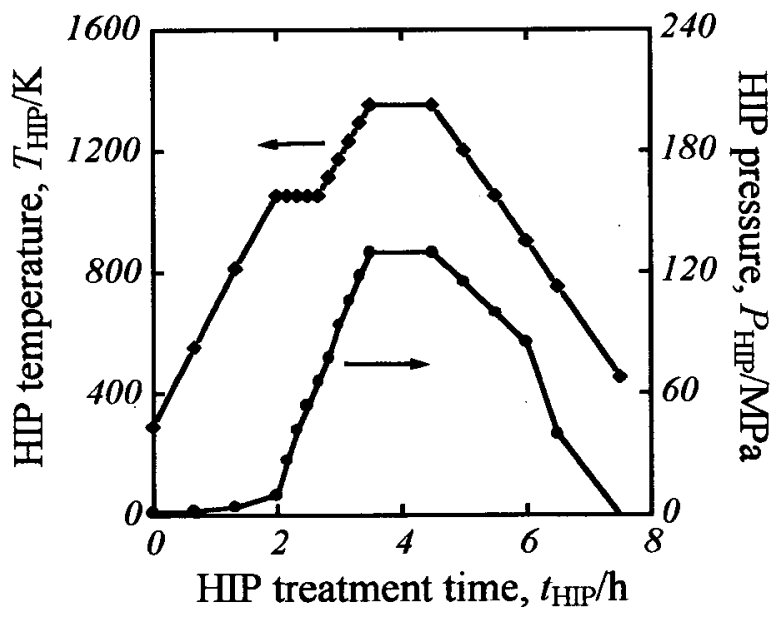

Fig.2 Schematic diagram of HIP treatment process.
焼結体の HIP 処理温度と相対密度との関係を示す. 処理温度 が高くなると相対密度が上昇する傾向にあるが，最も低い処

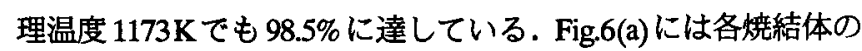
鏡面研磨処理を施した電子放射面のSEM写真を, Fig.6(b)には 硝酸でエッチングした電子放射面のSEM写真を示す.(a)の写 真から，(1)いずれの HIP処理温度において Ni粒子の周りをエ ミッタが完全に復い,緻密な組織になっていること, (2) $1173 \mathrm{~K}$ から $1273 \mathrm{~K} へ$ の HIP 処理温度の上昇に伴い, Ni の粒成長が見 られるが, Ni粒子の周りにエミッタが均一に分散して隣接す るNi粒子の間を遮断しており，1473Kまで温度を上昇させて も Ni粒子の大幅な粒成長は生じず, 組織の均質性が保たれて いることがわかる.また，(b)より，1373Kの HIP処理温度ま ではエミッタは微細な粒子の集合体として観察されるが， $1473 \mathrm{~K} て ゙ は エ ミ ッ タ の$ 粒成長が観察される。

Fig.7に各焼結体のX線回折図形を示す. 出発原料である三 元系炭酸塩 $\left(\mathrm{Ba}_{0.5}, \mathrm{Sr}_{0.4}, \mathrm{Ca}_{0.1}\right) \mathrm{CO}_{3}$ の回折図形はHIP処理後に変化 しているが，HIP 温度による変化は見られない. 出発原料は $\mathrm{Ba}, \mathrm{Sr}$ および Ca の化合物から合成したものであるが, HIP 処 理後の構造は今のところ同定できていない. HIP処理におけ る炭酸塩の安定性を知るために, $\mathrm{BaCO}_{3}$ 単体粉末と $\mathrm{Ni}$ 粉末と の混合粉末をカプセル封入して $1373 \mathrm{~K}, 130 \mathrm{MPa}, 1 \mathrm{~h}$ の HIP 処 理を行った. HIP 処理前後 X 線回折図形を Fig.8に示す. エ ミッタ出発原料の多数の回折ピークはHIPによって半価幅の 大きなピークに変化しており，熱影響を受けていることは明 らかであるが, 組成の大きな変化は生じていないと推測され る.少なくとも酸化物に変化していないことは, 酸化物特有 の潮解性が見られなかったことからも明らかである。

4.2 低温動作 HIP カソードの電子放射特性

\subsubsection{HIP 処理温度の最適条件}

Fig.9に熱活性温度1353Kにおける保持時間に対する動作温 度 $1053 \mathrm{~K} て ゙ の M I k$ の変化を示す。この特性評価では，最も短 時間に3000 $\mathrm{AA} M I k$ に達したとき最もエミッション特性が良 好であると判断される. HIP 処理温度 $1117 \mathrm{~K} \sim 1373 \mathrm{~K}$ では温度 が高いほど短時間に $3000 \mu \mathrm{A}$ に達した。 $1473 \mathrm{~K}$ の場合，1373K

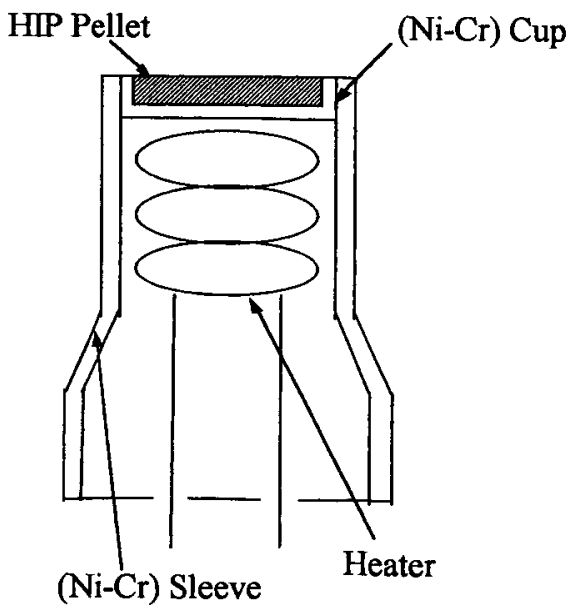

Fig.3 An example of HIP cathode construction. 

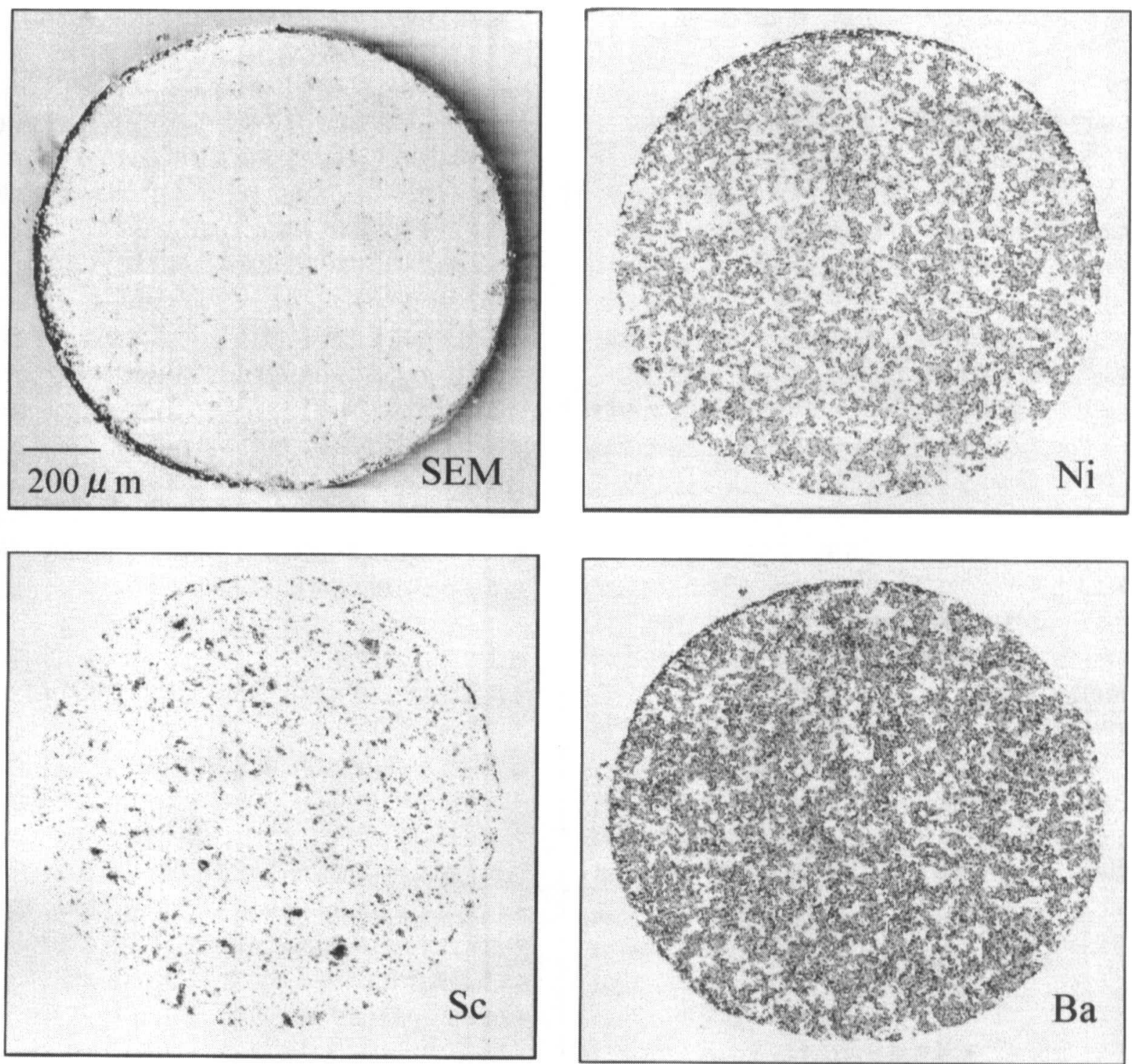

Fig.4 EPMA image of the pellet surface of the HIP cathode.

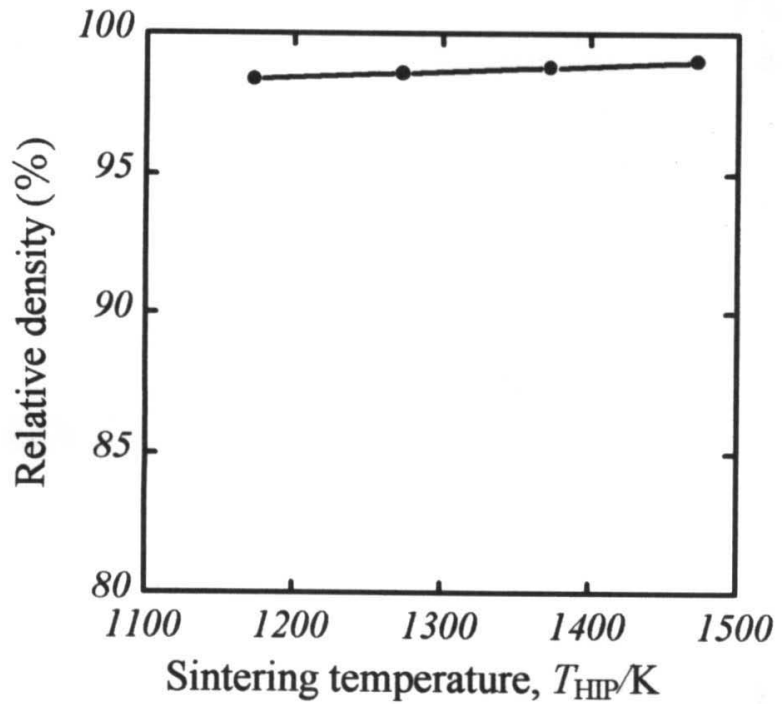

Fig.5 Effect of HIP temperature on relative density of HIP cathode compacts.
に比べ $M I k$ の飽和に時間を要し, 飽和する $M I k も 3000 \mu \mathrm{A} よ り$ 低い.この特性の劣化は, Fig.6に示したエミッ夕の粒成長に 関連して生じているものと推測されるが, その機構は, 今の ところ明らかでない。

\subsection{2 初期電子放射特性}

最もエミッション性能が良好である HIP 処理温度 $1373 \mathrm{~K}$ の 焼結体における電子放射特性の評価を実施した. Fig.10 に力 ソード温度 $\left(T_{\mathrm{K}}\right)$ と $M I k$ の関係を示す. $T_{\mathrm{K}}$ の上昇に伴って $M I k$ が増加し， $1053 \mathrm{~K} て ゙ 3000 \mu \mathrm{A}$ 達し飽和している. Fig.11に $T_{\mathrm{K}}$ が $1053 \mathrm{~K}$ のとのカソード駆動電圧とアノード電流の関係を示

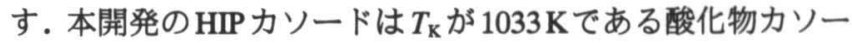
ドより $20 \mathrm{~K}$ 高い動作温度にて, 同等の駆動特性を有している. 4.2.3 寿命特性

HIPカソード及び酸化物カソードを搭載したCRTを用いて, 長期間の高電流密度印加寿命試験を実施した。実施条件は, 動作温度はそれそれ 1053K及び $1033 \mathrm{~K} ， 3$ 極管動作状態にお 


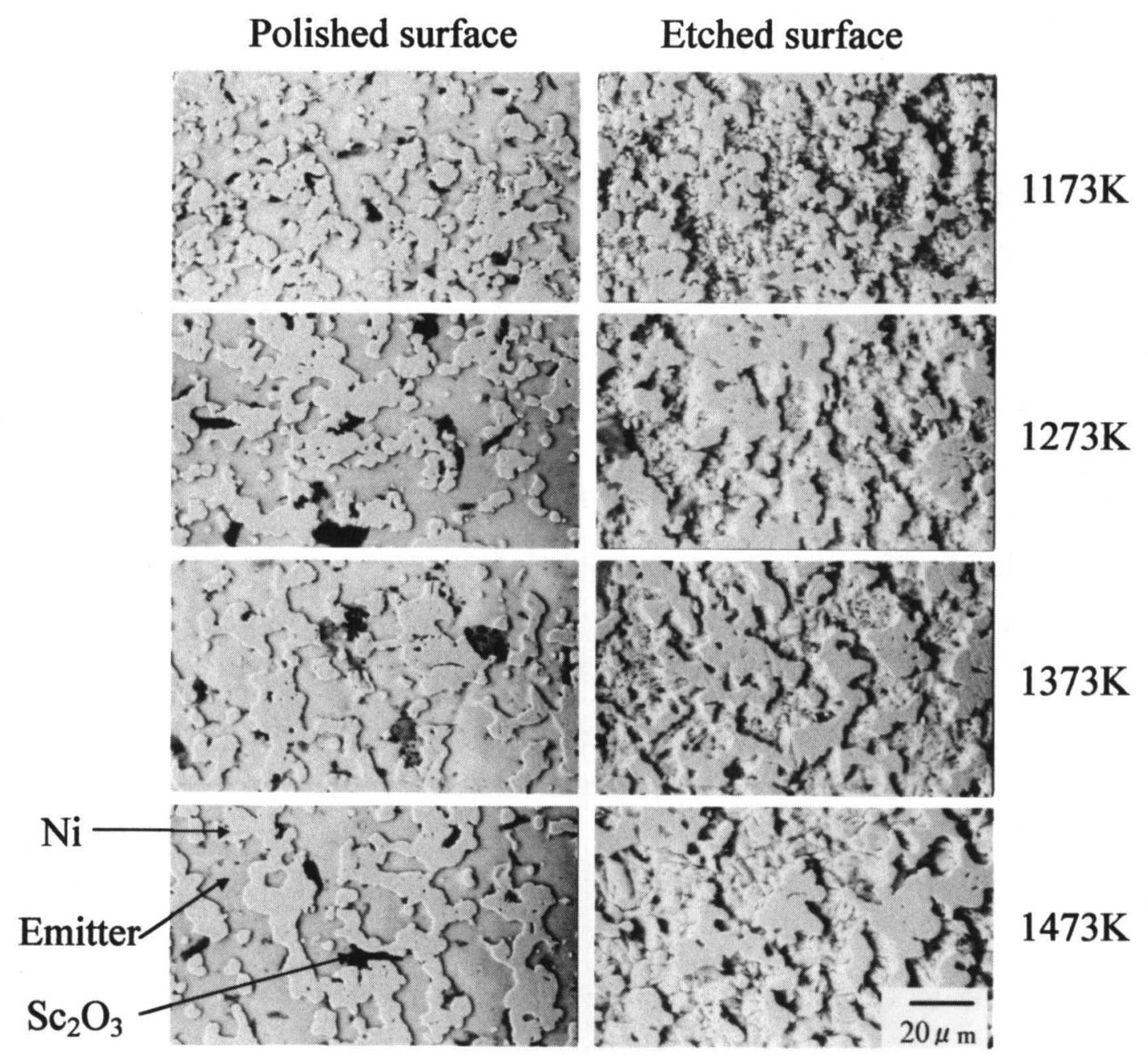

Fig.6 SEM photographs of surface of HIP cathodes operated at different HIP temperature (a) polished surface, (b) etched surface.

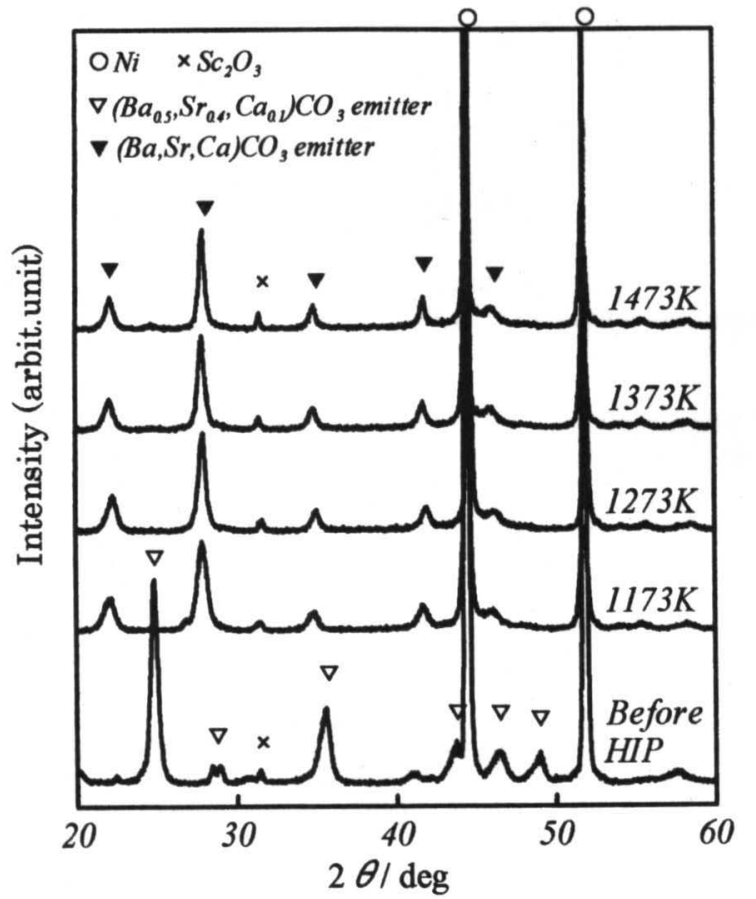

Fig.7 X-ray diffraction patterns of cathodes prepared at different HIP temperatures.

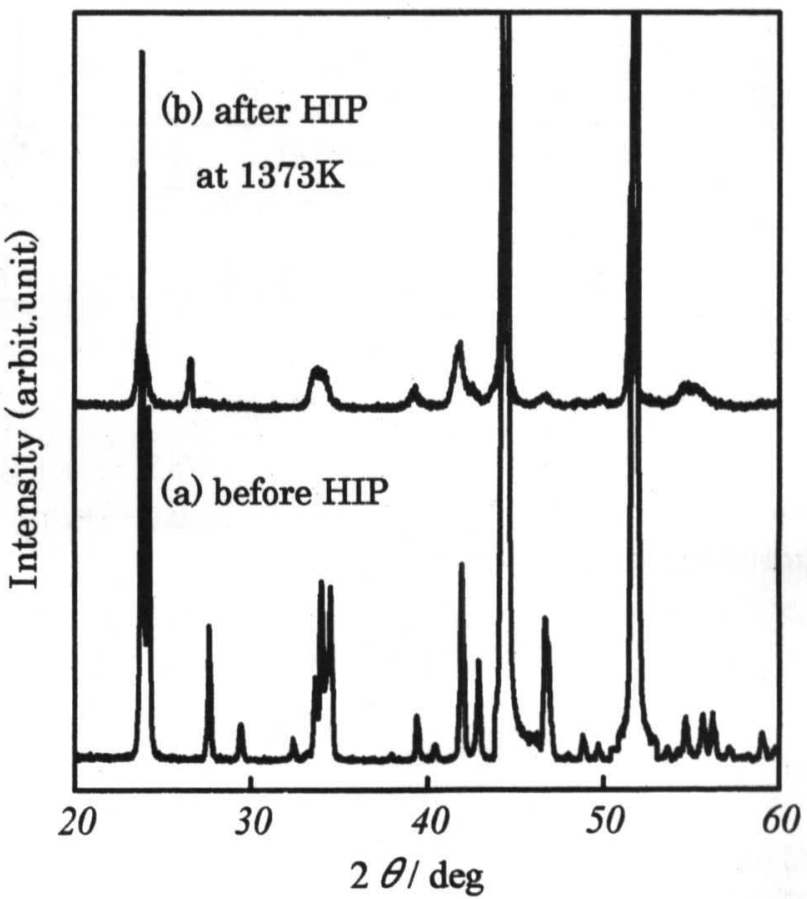

Fig.8 X-ray diffraction patterns of (a) before HIP and (b) after HIP at $1373 \mathrm{~K}$. 


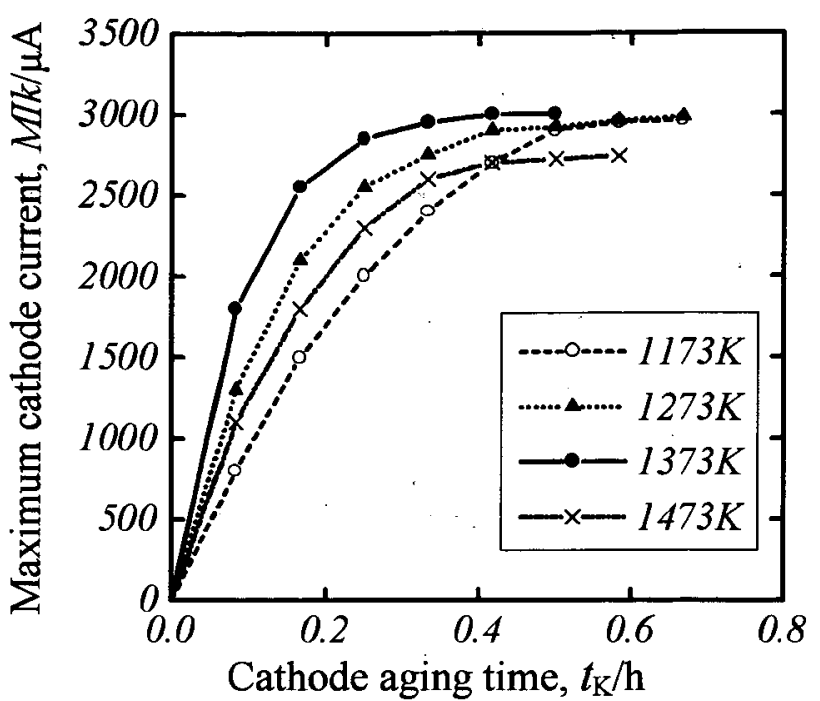

Fig.9 Relation between maximum cathode current (MIk) and cathode aging time of cathodes prepared at different HIP temperature.

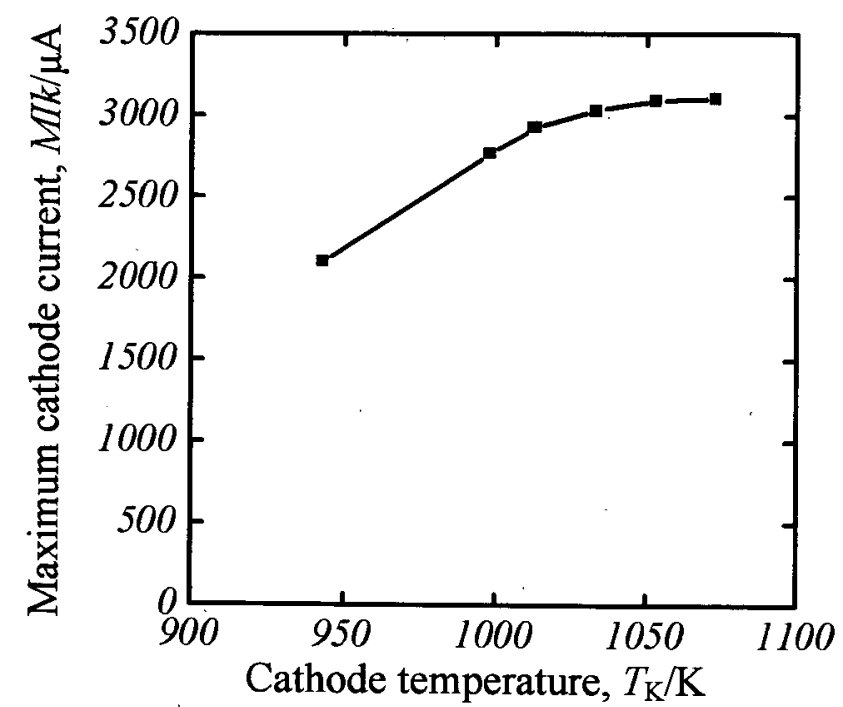

Fig.10 Maximum cathode current (MIk) characteristic of HIP cathodes.

ける平均電流密度 $3 \mathrm{~A} / \mathrm{cm}^{2}$ である. 寿命試験時間 $30000 \mathrm{~h}$ 経過 後のMIkの経時変化を Fig.12に示す. 酸化物カソードの場合, $M I k$ は約 $1000 h$ で半減しているにもかかわらず, HIPカソード の場合，30000h 経過時点でのエミッション低減は $10 \%$ 未満 で, 大電流印加に対する優れた寿命特性が明らかになった。

\section{5 結 言}

3 元系炭酸塭 $(\mathrm{Ba}, \mathrm{Sr}, \mathrm{Ca}) \mathrm{CO}_{3}$ 粉末と $\mathrm{Ni}$ 粉末を $\mathrm{HIP}$ 法により焼 結固化した低温動作 HIP カソードを開発した．本カソードの 特徵は以下の通りである。

(1) HIP 処理温度 $1173 \mathrm{~K} \sim 1373 \mathrm{~K}$ で作製した HIP カソードは,

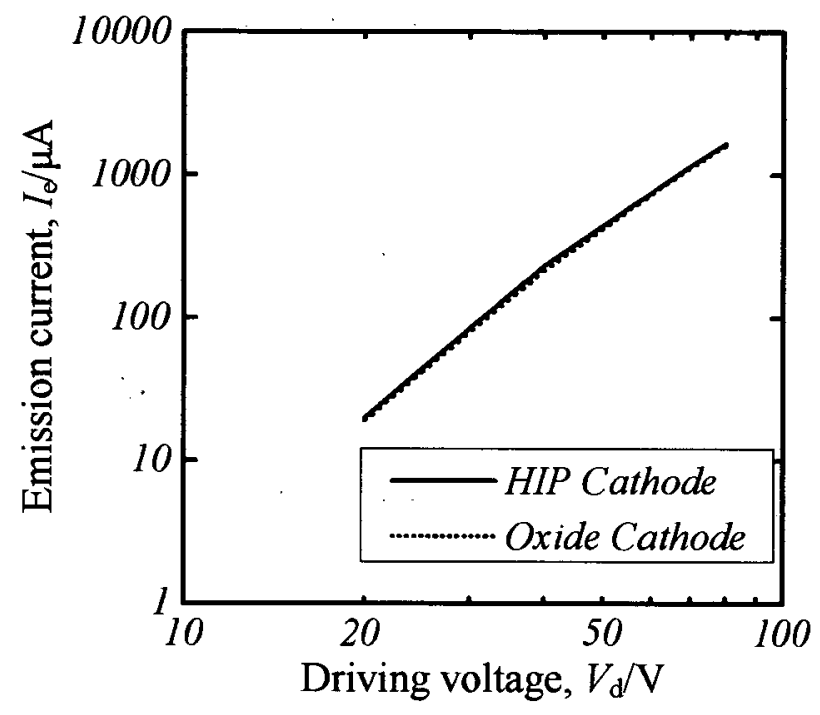

Fig.11 Driving voltage characteristic of HIP cathodes and Oxide cathodes.

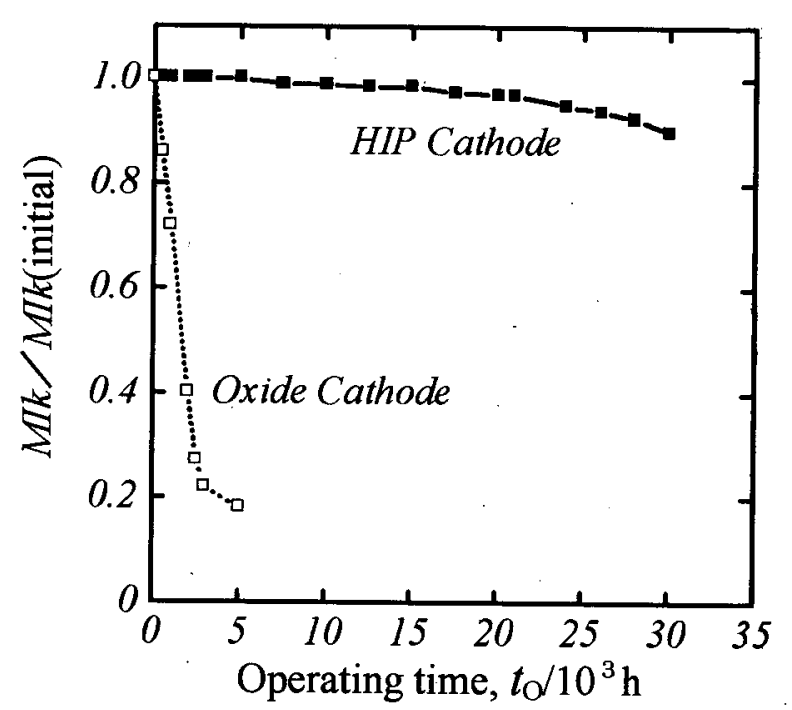

Fig.12 Life characteristic of a HIP cathode and an Oxide cathode for a current density of $3 \mathrm{~A} / \mathrm{cm}^{2}$.

沉用の酸化物カソードと同様の枯化処理によって,良好な エミッション性能を示した. 特に, HIP処理温度 $1373 \mathrm{~K}$ の 場合, 最も短時間で枯化処理ができ, 酸化物カソードとほ ぼ同様の動作温度 $1053 \mathrm{~K} て ゙$ 良好なエミッション特性が得 られた。

(2) HIP 処理温度が $1373 \mathrm{~K}$ の HIP カソードは, 平均電流密度 $3 \mathrm{~A} / \mathrm{cm}^{2}$ の高電流印加寿命試験における 30000 時間経過時 点で最大カソード電流の低減率が $10 \%$ 未満の優れた寿命 特性を示した。

(3) HIP 焼結体は室温の大気中で安定であり，湿式によるぺ レット化加工が可能である。 


\section{文献}

1) J.L.Cronin: "Modern dispenser cathodes", IEE PROC., Vol.128, Pt.I, (1981)19-32.

2) 松本貞雄, 木村栄, 矢壁徹, 宮崎大輔: "高品位 CRT 用含浸 型カソード", 信学技報, EID90-32, (1990)1-5.

3）遠藤順,佐々木紳二, 中川智: "CRT 用含浸型カソード", 信 学技報, EID89-75, (1989)7-12.

4) K.Ebe, M.Kawase, S.Yamazaki, A.Yoshida, Y.Hara, H.Takamura, Y.Yoshioka, S.Oguchi, T.Kusunoki, K.Ono and T.Ube: "A New 24-in. 16:10 Trinitron CRT", SID 97 Digest, (1997)142-145.

5) M.Saito, M.Ishida, K.Fukuyama, K.Watanabe, T.Kamata, K.Sano and H.Nakanishi: "High Current Density Oxide Cathode for CRT", NTG Fachberichte, 95(1986)165-170.

6) H.Teramoto, T.Ohira, M.Saito and T.Shinjo: "An Oxide Cathode with Tungsten-Film Coating", IDW '98, (1998)453-456.

7) M.Nakamura, T.Makino, S.Soematsu and T.Saito: "A 45-in Flatand-Square Trinitron Color CRT", SDI 88DIGEST, (1988)386-388.

8) 杉村俊和, 成田万紀, 北村幹夫: "HIP 法による含浸力ソー ドの焼結と電子放射特性", 粉体および粉末治金, 39(1992) 260-265.

9) T.Sugimura, M.Narita, R.Takeda and T.Hirai: "A Newly Developed HIP Cathode Sintered under High Temperature and High Pressure", IDW '99, (1999)533-536. 